\title{
Immune Checkpoint Inhibitor- Associated Type 1 Diabetes Mellitus: Case Series, Review of the Literature, and Optimal Management
}

\author{
Jonathan Kapke $^{\mathrm{a}}$ Zachary Shaheen $^{\mathrm{b}}$ Deepak Kilari $^{\mathrm{c}}$ Paul Knudson $^{\mathrm{d}}$ \\ Stuart Wong ${ }^{\mathrm{e}}$ \\ aDivision of Hematology and Oncology, Medical College of Wisconsin, \\ Milwaukee, WI, USA; ${ }^{b}$ Department of Medicine, Medical College of Wisconsin, \\ Milwaukee, WI, USA; ' ${ }^{\mathrm{D}}$ ivision of Hematology and Oncology, Medical College of \\ Wisconsin, Milwaukee, WI, USA; ${ }^{d}$ Division of Endocrinology, Medical College of Wisconsin, \\ Milwaukee, WI, USA; ${ }^{e}$ Division of Hematology and Oncology, Medical College of \\ Wisconsin, Milwaukee, WI, USA
}

\section{Keywords}

Immunology · Immunotherapy · Checkpoint inhibitor · Autoimmunity · Diabetes mellitus

\section{Abstract}

With the introduction of immune checkpoint inhibitors into clinical practice, various autoimmune toxicities have been described. Antibodies targeting the receptor:ligand pairing of programmed death receptor-1 (PD-1) and its cognate ligand programmed death-ligand 1 (PD-L1) in rare reports have been associated with autoimmune diabetes mellitus. We report 2 cases of rapid-onset, insulin-dependent, type 1 diabetes mellitus in the setting of administration of nivolumab, a fully human monoclonal antibody to PD-1, and atezolizumab, a humanized monoclonal antibody to PD-L1. This appears to be the first report of autoimmune diabetes mellitus associated with atezolizumab. In addition, we provide a brief review of similar 


\section{Case Reports in Oncology}

Case Rep Oncol 2017;10:897-909

DOI: $10.1159 / 000480634$

(c)

(C) 2017 The Author(s). Published by S. Karger AG, Base www.karger.com/cro

Kapke et al.: Immune Checkpoint Inhibitor-Associated Type 1 Diabetes Mellitus: Case Series, Review of the Literature, and Optimal Management

cases reported in the literature and a discussion of potential mechanisms for this phenomenon and propose a diagnostic and treatment algorithm.

\section{Introduction}

Immune checkpoints refer to inhibitory signaling pathways in immune cells that are regulated by a number of receptor:ligand pairings. Two of the most actively studied inhibitory receptors are cytotoxic T-lymphocyte-associated antigen 4 (CTLA-4), which binds to the B7 family ligands B7-1 (CD80) and B7.2 (C86), and programmed death receptor-1 (PD-1), which binds to its cognate ligand programmed death-ligand 1 (PD-L1) [1, 2]. Tumor cells have long been known to aberrantly express these immune checkpoint molecules to inhibit antitumor immune responses $[1,2]$. Immune checkpoint inhibition has emerged as a pharmacological mechanism that augments endogenous antitumor immune responses during the treatment of malignancies [1]. These checkpoint inhibitors are antibodies which bind to block inhibitory signaling pathways, principally in T lymphocytes, which enhance the activation of tumor-specific cytotoxic T cells [1]. In recent years, a number of immune checkpoint inhibitors have been approved for tumor therapy, including nivolumab (fully human monoclonal IgG4 antibody to PD-1) and atezolizumab (humanized monoclonal IgG1 antibody to PD-L1).

While inhibition of peripheral T-cell activation is a mechanism by which tumors evade the immune system, these immune checkpoints also serve to maintain peripheral tolerance of self-antigens. Therefore, pharmacological inhibition of immune checkpoints has the potential to both enhance antitumor immunity and to either stimulate or enhance autoimmunity. Indeed, there are several reports in animal models that mechanistically demonstrate that either genetic deletion or pharmacological inhibition of these immune checkpoint molecules (PD-1 and PD-L1) enhance the rate and incidence of autoimmune diabetes [3-6]. While there are multiple reports that describe a temporal association between the use of PD- 1 inhibitors for tumor therapy and the rapid induction of a late-onset autoimmune diabetes mellitus [717], only two reports to date associate PD-L1 inhibitors with diabetes mellitus (BMS-936559 [18] and an unspecified PD-L1 inhibitor [13]).

We present 2 case reports: first, an 83-year-old male who presented with diabetic ketoacidosis (DKA) and antibody-positive type 1 diabetes mellitus (T1DM) following treatment with nivolumab and systemic chemotherapy for metastatic squamous cell carcinoma of the right posterior maxillary sinus; and second, a 63-year-old female who presented with DKA and antibody-positive T1DM following treatment with atezolizumab and systemic chemotherapy for high-grade urothelial carcinoma of the bladder (Table 1). In addition, we provide a literature review of T1DM following treatment with PD-L1 or PD-1 inhibitors, discuss potential mechanisms for this phenomenon, and propose a diagnostic and treatment algorithm. 


\section{Case Reports in Oncology}

\section{Case Presentation 1}

An 83-year-old male with a past medical history of tobacco smoking, chronic sinusitis, and hypothyroidism presented to his dentist with premaxillary pain. Cone beam computed tomography (CT) imaging was obtained demonstrating radiolucency around tooth 8 and 9. He was seen by a periodontist who biopsied the lesion, and pathology was significant for squamous cell carcinoma. Positron emission tomography (PET) imaging showed fludeoxyglucose avidity in the left paramedian maxillary alveolar ridge, the right maxillary sinus, and two lesions in the liver. The patient was taken to the operating room and underwent nasal endoscopy with biopsy of the right posterior maxillary sinus wall with pathology confirming squamous cell carcinoma. Ultrasound-guided core liver biopsy was positive for metastatic poorly differentiated squamous cell carcinoma. The patient was treated with transarterial chemoembolization to the liver and radiation therapy to the maxillary sinus.

Surveillance imaging one month after initial therapy, including magnetic resonance imaging of the brain, demonstrated a new $1.0 \mathrm{~cm}$ posterior right frontal lobe lesion concerning for metastasis. The patient was treated with stereotactic body radiation therapy with a total of 30 Gy delivered in six fractions to his brain lesion. Repeat PET imaging four months later was significant for a $2.4 \mathrm{~cm}$ mediastinal mass concerning for metastasis.

The patient was started on systemic therapy with nivolumab, a fully humanized immunoglobulin that blocks PD-1. The medication was administered as $240 \mathrm{mg}$ i.v. every 14 days.

Approximately 3 months later, the patient was admitted to the hospital with clinical features of DKA, including a blood glucose level of $426 \mathrm{mg} / \mathrm{dL}$, serum bicarbonate of 14 $\mathrm{mmol} / \mathrm{L}$, serum $\mathrm{pH}$ of 7.29 , an elevated anion gap of 26 , and ketonuria. He was treated with insulin and clinically improved. Additional laboratory testing included low C-peptide at 0.32 $\mathrm{ng} / \mathrm{mL}$ (normal range 1.10-4.40 ng/mL) and elevated anti-glutamic acid decarboxylase (GAD) antibody levels at 1,763.6 U/mL (normal range 0.0-5.0 U/mL). Low-resolution human leukocyte antigen (HLA) typing demonstrated DRB1*08, DRB1*11, DQB1*03, DQB1*04, DQA $1 * 04$, and DQA1*05. Serologic equivalents include DR8,11; DQ4,7. These particular HLA types are not commonly associated with high-risk genotypes for T1DM. Since hospital discharge, the patient has remained insulin dependent, with stable insulin requirements and stable blood glucose levels. Both his insulin requirements and glucose variability are consistent with T1DM.

Of note, shortly after hospitalization for DKA, the patient developed progressive diarrhea and bloody stool. Colonoscopy was significant for diffuse colitis. Nivolumab was discontinued, and the patient was started on prednisone $60 \mathrm{mg}$ p.o. daily. Steroids were slowly tapered and then discontinued after approximately 2 months of treatment. The patient's colitis symptoms resolved. He remains off nivolumab and is followed with clinical observation. The most recent restaging CT imaging demonstrated stable disease without evidence of progression or new metastasis.

\section{Case Presentation 2}

A 63-year-old female with a history of hypothyroidism and iron deficiency anemia with reactive thrombocytosis and leukocytosis initially presented with hematuria. The patient 


\section{Case Reports in Oncology}

underwent cystoscopy with transurethral removal of bladder tumor (TURBT) significant for a large bladder tumor involving the dome, left side wall, right trigone, right side wall, and bladder neck. Pathology was significant for high-grade urothelial carcinoma with papillomatous squamous differentiation. No lamina propria or muscularis propria invasion was present consistent with cT1 disease. She was treated with adjuvant Bacillus Calmette-Guérin (BCG).

Four months later, the patient had surveillance cystoscopy significant for two large recurrent masses in the base of the bladder. Restaging CT scan suggested perivesicular involvement concerning for cT3 disease. The patient was started on neoadjuvant gemcitabine and cisplatin followed by cystectomy. Surgical pathology was significant for pT2b urothelial carcinoma. Restaging scans four months postoperatively showed no evidence of disease.

Ten months postoperatively, the patient had restaging CT scans demonstrating a $3.8 \times$ $2.5 \mathrm{~cm}$ lymph node mass in the mediastinum and two pulmonary nodules concerning for metastatic disease. She underwent right paratracheal lymph node biopsy with pathology consistent with metastatic high-grade urothelial carcinoma. The patient was started on atezolizumab, a humanized monoclonal antibody immune checkpoint inhibitor that binds to PD-L1. The medication was administered as $200 \mathrm{mg}$ i.v. every three weeks.

Cycle one of treatment was complicated by drug fever and increased thyroid-stimulating hormone, requiring dose escalation of the patient's levothyroxine. During cycle two of therapy, the patient was hospitalized with clinical evidence of DKA, including a blood glucose level of $801 \mathrm{mg} / \mathrm{dL}$, serum bicarbonate of $14 \mathrm{mmol} / \mathrm{L}$, an elevated anion gap of 28, and ketonuria. She was treated with an insulin infusion and clinically improved. Further laboratory testing was significant for a low C-peptide of $0.02 \mathrm{ng} / \mathrm{mL}$ (normal range 1.10-4.40 ng/mL) and an elevated anti-GAD antibody level at $>250.0 \mathrm{U} / \mathrm{mL}$ (normal range $0.0-5.0 \mathrm{U} / \mathrm{mL}$ ). Lowresolution HLA typing was significant for DRB1*03, DRB1*04, DQB1*02, DQB1*03, DQA1*03, and DQA1*05. Serologic equivalents include HLA-DR4,17; DQ2,8. DR4-DQ8 has been associated with high risk to develop T1DM [19]. The patient continued insulin at hospital discharge; she has remained insulin dependent with stable insulin requirements and stable blood glucose.

While on atezolizumab, the patient initially demonstrated a partial response to therapy. The most recent restaging CT imaging, prior to cycle 9 of immunotherapy, demonstrated overall stable disease except for a new $7 \mathrm{~mm}$ pulmonary nodule suspicious for metastasis. While working on prior authorization for alternative therapy, the patient was admitted to the hospital with acute hypoxic respiratory failure in the setting of pericardial effusion with cardiac tamponade and distal tracheal narrowing. She underwent pericardial window followed by tracheal stenting. Unfortunately, the patient's postoperative course was complicated by worsening respiratory failure. She elected to transition to hospice care and passed away shortly thereafter.

\section{Discussion}

Immunity to cancer cells requires a complex, multistep process. First, cancer cell death releases tumor antigen, then antigen must be processed and presented by antigenpresenting cells, antigen-presenting cells and $\mathrm{T}$ cells must be primed, then cytotoxic $\mathrm{T}$ lym- 


\section{Case Reports in Oncology}

phocytes must travel through the bloodstream to tumor cells, infiltrate tumor tissue via endothelial cells, recognize cancer cells, and destroy them. Each step in this process must be completed to achieve a clinically meaningful response [20].

Cancer cells have evolved to develop mechanisms that disrupt this process. One notable pathway utilized by malignant cells to inhibit cytotoxic T-lymphocyte recognition and destruction of tumor cells involves the receptor:ligand pairing of PD-1:PD-L1 [21]. PD-1 is present on activated T cells [22]. PD-L1 is found on hematologic cells, such as B cells, dendritic cells, macrophages, and T cells as well as various stromal cells, such as vascular endothelial cells and pancreatic islet cells [4, 23, 24]. When PD-1 interacts with PD-L1, an inhibitory signal is generated that regulates T-cell activation, tolerance, and cytotoxic activity $[25,26]$. Cancer cells expressing PD-L1 can take advantage of this inhibitory signal to evade immune response [27].

Immune checkpoint inhibitors are monoclonal antibodies targeting various receptor:ligand pairs that function to modulate T-cell activity. Nivolumab is a fully human monoclonal antibody that selectively inhibits PD-1, while atezolizumab is a humanized monoclonal antibody that binds to PD-L1. Immune checkpoint inhibitors aim to restore antitumor immune response but also increase the risk for autoimmunity [28, 29]. With the approval of immune checkpoint inhibitors, various autoimmune toxicities have been described in the literature. One rare phenomenon includes autoimmune diabetes mellitus [30].

The two cases reported here describe the development of late-onset, insulin-dependent, autoimmune diabetes mellitus (i.e., T1DM) in association with the administration of both anti-PD-1 and anti-PD-L1 immune checkpoint inhibitors. Upon review of the literature, our first patient appears to be the 12th reported case of T1DM associated with the administration of nivolumab (anti-PD-1), while our second patient appears to be the first reported case of T1DM associated with the administration of atezolizumab (anti-PD-L1) (Table 2) [8-12, 14-17].

Patient characteristics for those diagnosed with autoimmune diabetes mellitus associated with the administration of nivolumab have been variable. Most cases have been observed in patients with melanoma, but it has also been described in non-small cell lung cancer, renal cell carcinoma, small cell lung cancer, and Hodgkin lymphoma [8-12, 14-17]. The higher incidence in melanoma could potentially be explained by the increased use of immune checkpoint inhibitors in this population over recent years. Although many patients present within two to three months of starting treatment, some cases have also been described as far as twelve months from initiating immunotherapy. All cases have been associated with newonset hyperglycemia, and the majority of patients presented with DKA. All patients presented with low fasting C-peptide, most were found to have one of the known autoantibodies associated with autoimmune diabetes mellitus, and all remained insulin dependent after initial presentation $[13,18]$.

Our second patient appears to be the first reported case of T1DM associated with atezolizumab. In a review of the literature for all anti-PD-L1 antibodies, this appears to be the third reported case. The first case was described in the initial phase 1 study for BMS-936559, a fully human PD-L1-specific monoclonal antibody that inhibits the binding of PD-L1 to both PD-1 and CD80. Details of this patient's clinical presentation, diagnostic workup, and treatment were not disclosed [18]. The second reported case described a 70-year-old man with advanced non-small cell lung cancer who received an unspecified PD-L1 antibody. His course 


\section{Case Reports in Oncology}

was complicated by DKA. Diagnostic studies were significant for low C-peptide of $0.3 \mathrm{ng} / \mathrm{mL}$ (normal range 1.0-7.1 ng/mL) and undetectable insulin autoantibody and anti-GAD antibody. Additional autoantibody testing and HLA typing was not performed. The patient remained insulin dependent and died of disease progression seven months later.

T1DM results from the autoimmune destruction of the insulin-producing $\beta$ cells of the endocrine pancreas [31]. Individual susceptibility is largely influenced by various genetic factors, including both major histocompatibility complex (MHC) and non-MHC genes [3234]. The dominant susceptibility genes for T1DM are found on the HLA region of chromosome $6 p$, which encodes for MHC class II molecules $[35,36]$. While there have been various HLA genotypes associated with a high risk to develop autoimmune diabetes mellitus, over $90 \%$ of type 1 diabetics carry either DR3,DQB1*0201 (also known as DR3-DQ2) or DR4,DQB1*0302 (also known as DR4-DQ8), and up to 30\% have both haplotypes (DR3/DR4 heterozygotes), which is associated with the greatest risk for the development of autoimmune diabetes [36]. Multiple non-HLA factors have been shown to influence the risk for T1DM, which broadly function to regulate antiviral responses, lymphocyte activation, chemokine and cytokine signaling, and peripheral tolerance [33, 35].

Several autoantigens isolated from pancreatic islet cells are associated with the development of autoimmune diabetes mellitus, including GAD, insulin, insulinoma-associated protein 2 (IA-2), and zinc transporter (ZnT8) [37]. While the specific role of humoral immunity in the pathogenesis of autoimmune diabetes mellitus is incompletely understood, the majority of $\beta$ cells are selectively destroyed in a mechanism dependent on T cells [33, 38]. Histopathological studies reviewing post mortem sections of the pancreas from type 1 diabetics have demonstrated that the majority of infiltrating immune cells are CD8+ T cells [39], and in animal models either removal or transfer of CD4+ or CD8+ T cells can prevent or precipitate diabetes, respectively [38, 40, 41].

Multiple pathways have been studied to better understand the mechanisms regulating $\mathrm{T}$-cell tolerance to self-antigens. One of the main sources of peripheral tolerance induction is CD4+CD25+FoxP3+ regulatory T cells (Tregs). Limited function and number of this Treg population has been implicated in autoimmune diabetes mellitus [42]. IL-10 secretion by Tregs functions to induce anergy and apoptosis of activated effector CD4+ and CD8+ T cells. Additionally, multiple T-cell populations, including Tregs, also express the inhibitory receptors CTLA-4 and PD-1, which bind to the B7 family ligands B7-1 (CD80) and B7.2 (C86), and PD-L1, respectively.

Recent investigations in animal models provide evidence that either genetic deletion or pharmacological interruption of PD-1:PD-L1 interaction promotes the development of diabetes mellitus [3-6]. Importantly, pancreatic islet cells also express PD-L1 [43-46], which also functions to help maintain peripheral tolerance. B7-1 (CD80), a ligand for CD28 and CTLA-4, has also been shown to be a second binding site for PD-L1 in both mice and humans. It has been observed that the most commonly used anti-PD-L1 monoclonal antibodies may also block the interaction between PD-L1 with both PD-1 and B7-1 [47-50], which likely functions to release B7 to bind to T-cell costimulatory receptor CD28. These data suggest that the interaction of PD-L1 with PD-1 and B7-1 provides an immunoinhibitory effect against self-reactive effector T cells and that disruption of the PD-1:PD-L1 and PD-L1:B7-1 pairings with anti-PD-L1 monoclonal antibodies blocks peripheral inhibitory signals on cytotoxic T lymphocytes, stimulating autoimmune destruction of pancreatic islet cells. 


\section{Case Reports in Oncology}

When a clinician is confronted with new-onset hyperglycemia in the setting of immune checkpoint inhibitor therapy, prompt diagnostic evaluation should be initiated (Table 3). In addition to workup and management of hyperglycemia and potentially DKA, laboratory testing to consider includes fasting C-peptide as well as various antibody markers associated with autoimmune diabetes mellitus, including GAD, insulin autoantibody, IA-2, and zinc transporter (ZnT8). One would anticipate a low fasting C-peptide and elevated antibody markers in autoimmune diabetes mellitus; however, this is not always the case.

In general, treatment for moderate to severe immune-related adverse events associated with immune checkpoint inhibitors has been delaying therapy and immunosuppression with corticosteroids. However, this approach may not be as useful in the setting of immunotherapy-related autoimmune diabetes. Studies suggest that in type 1 diabetics, by the time hyperglycemia manifests clinically, up to $80-95 \%$ of pancreatic $\beta$-cell mass has been irreversibly lost [51-56]. With such a significant loss of $\beta$ cells at the time of clinical presentation, it seems unlikely that immunotherapy dose modification or immunosuppression would alter the course of autoimmunity or insulin dependence. Therefore, in the setting of rapid-onset, autoimmune, insulin-dependent diabetes associated with immune checkpoint inhibitor therapy, there seems to be limited utility to immunotherapy dose modification or immunosuppression with corticosteroids. We propose managing hyperglycemia with insulin therapy and continuing immune checkpoint inhibition unless other clinical factors, such as alternative toxicity or disease progression, require dose modification or discontinuation.

\section{Conclusion}

Immune checkpoint inhibitors have been associated with various immune-related adverse effects. Rare cases of autoimmune diabetes mellitus have been reported. We present two cases of rapid-onset, insulin-dependent T1DM associated with the administration of nivolumab and atezolizumab. This appears to be the first report of autoimmune diabetes mellitus associated with atezolizumab. Based on a review of the literature, the PD-1:PD-L1 pathway seems to provide a protective effect against $\beta$ cell autoimmunity, and in some patients, blocking this pairing with immune checkpoint inhibitors may lead to autoimmune diabetes mellitus and insulin dependence. There seems to be limited utility of dose modification or immunosuppression with corticosteroids once patients develop hyperglycemia. Further research is needed to clarify how to identify patients at greatest risk for autoimmunity and to determine the optimal strategy for prevention and management.

\section{Statement of Ethics}

The authors have no ethical conflicts to disclose. Informed consent was obtained from the patients for this report. 


\section{Disclosure Statement}

The authors declare that there are no conflicts of interest.

\section{References}

1 Pardoll DM: The blockade of immune checkpoints in cancer immunotherapy. Nat Rev Cancer 2012;12:252-264.

-2 Zamani MR, Aslani S, Salmaninejad A, Javan MR, Rezaei N: PD-1/PD-L and autoimmunity: a growing relationship. Cell Immunol 2016;310:27-41.

- Guleria I, Gubbels Bupp M, Dada S, Fife B, Tang Q, Ansari MJ, Trikudanathan S, Vadivel N, Fiorina P, Yagita H, Azuma M, Atkinson M, Bluestone JA, Sayegh MH: Mechanisms of PDL1-mediated regulation of autoimmune diabetes. Clin Immunol 2007;125:16-25.

-4 Ansari MJ, Salama AD, Chitnis T, Smith RN, Yagita H, Akiba H, Yamazaki T, Azuma M, Iwai H, Khoury SJ, Auchincloss H Jr, Sayegh MH: The programmed death-1 (PD-1) pathway regulates autoimmune diabetes in nonobese diabetic (NOD) mice. J Exp Med 2003;198:63-69.

5 Wang J, Yoshida T, Nakaki F, Hiai H, Okazaki T, Honjo T: Establishment of NOD-Pdcd1-/- mice as an efficient animal model of type I diabetes. Proc Natl Acad Sci USA 2005;102:11823-11828.

6 Yadav D, Hill N, Yagita H, Azuma M, Sarvetnick N: Altered availability of PD-1/PD ligands is associated with the failure to control autoimmunity in NOD mice. Cell Immunol 2009;258:161-171.

7 Chae YK, Chiec L, Mohindra N, Gentzler R, Patel J, Giles F: A case of pembrolizumab-induced type-1 diabetes mellitus and discussion of immune checkpoint inhibitor-induced type 1 diabetes. Cancer Immunol Immunother 2017;66:25-32.

-8 Gaudy C, Clevy C, Monestier S, Dubois N, Preau Y, Mallet S, Richard MA, Grob JJ, Valero R, Beliard S: AntiPD1 pembrolizumab can induce exceptional fulminant type 1 diabetes. Diabetes Care 2015;38:e182e183.

\$ Hansen E, Sahasrabudhe D, Sievert L: A case report of insulin-dependent diabetes as immune-related toxicity of pembrolizumab: presentation, management and outcome. Cancer Immunol Immunother 2016;65:765-767.

-10 Hofmann L, Forschner A, Loquai C, Goldinger SM, Zimmer L, Ugurel S, Schmidgen MI, Gutzmer R, Utikal JS, Goppner D, Hassel JC, Meier F, Tietze JK, Thomas I, Weishaupt C, Leverkus M, Wahl R, Dietrich U, Garbe C, Kirchberger MC, Eigentler T, Berking C, Gesierich A, Krackhardt AM, Schadendorf D, Schuler G, Dummer R, Heinzerling LM: Cutaneous, gastrointestinal, hepatic, endocrine, and renal side-effects of anti-PD-1 therapy. Eur J Cancer 2016;60:190-209.

11 Hughes J, Vudattu N, Sznol M, Gettinger S, Kluger H, Lupsa B, Herold KC: Precipitation of autoimmune diabetes with anti-PD-1 immunotherapy. Diabetes Care 2015;38:e55-e57.

12 Martin-Liberal J, Furness AJ, Joshi K, Peggs KS, Quezada SA, Larkin J: Anti-programmed cell death-1 therapy and insulin-dependent diabetes: a case report. Cancer Immunol Immunother 2015;64:765767.

13 Mellati M, Eaton KD, Brooks-Worrell BM, Hagopian WA, Martins R, Palmer JP, Hirsch IB: Anti-PD-1 and anti-PDL-1 monoclonal antibodies causing type 1 diabetes. Diabetes Care 2015;38:e137-e138.

14 Miyoshi Y, Ogawa 0, Oyama Y: Nivolumab, an anti-programmed cell death-1 antibody, induces fulminant type 1 diabetes. Tohoku J Exp Med 2016;239:155-158.

15 Munakata W, Ohashi K, Yamauchi N, Tobinai K: Fulminant type I diabetes mellitus associated with nivolumab in a patient with relapsed classical Hodgkin lymphoma. Int J Hematol 2017;105:383-386.

16 Okamoto M, Okamoto M, Gotoh K, Masaki T, Ozeki Y, Ando H, Anai M, Sato A, Yoshida Y, Ueda S, Kakuma T, Shibata H: Fulminant type 1 diabetes mellitus with anti-programmed cell death-1 therapy. J Diabetes Invest 2016; 7:915-918.

17 Teramoto Y, Nakamura Y, Asami Y, Imamura T, Takahira S, Nemoto M, Sakai G, Shimada A, Noda M, Yamamoto A: Case of type 1 diabetes associated with less-dose nivolumab therapy in a melanoma patient. J Dermatol 2017;44:605-606.

18 Brahmer JR, Tykodi SS, Chow LQ, Hwu WJ, Topalian SL, Hwu P, Drake CG, Camacho LH, Kauh J, Odunsi K, Pitot HC, Hamid O, Bhatia S, Martins R, Eaton K, Chen S, Salay TM, Alaparthy S, Grosso JF, Korman AJ, Parker SM, Agrawal S, Goldberg SM, Pardoll DM, Gupta A, Wigginton JM: Safety and activity of anti-PDL1 antibody in patients with advanced cancer. N Engl J Med 2012;366:2455-2465. 


\section{Case Reports in Oncology}

Nguyen C, Varney MD, Harrison LC, Morahan G: Definition of high-risk type 1 diabetes HLA-DR and HLA-DQ types using only three single nucleotide polymorphisms. Diabetes 2013;62:2135-2140. Chen DS, Mellman I: Oncology meets immunology: the cancer-immunity cycle. Immunity 2013;39:1-10. Stewart TJ, Abrams SI: How tumours escape mass destruction. Oncogene 2008;27:5894-5903. Agata Y, Kawasaki A, Nishimura H, Ishida Y, Tsubata T, Yagita H, Honjo T: Expression of the PD-1 antigen on the surface of stimulated mouse T and B lymphocytes. Int Immunol 1996;8:765-772. Yamazaki T, Akiba H, Iwai H, Matsuda H, Aoki M, Tanno Y, Shin T, Tsuchiya H, Pardoll DM, Okumura K, Azuma M, Yagita H: Expression of programmed death 1 ligands by murine T cells and APC. J Immunol 2002;169:5538-5545.

Liang SC, Latchman YE, Buhlmann JE, Tomczak MF, Horwitz BH, Freeman GJ, Sharpe AH: Regulation of PD-1, PD-L1, and PD-L2 expression during normal and autoimmune responses. Eur J Immunol 2003;33:2706-2716.

Carter L, Fouser LA, Jussif J, Fitz L, Deng B, Wood CR, Collins M, Honjo T, Freeman GJ, Carreno BM: PD1:PD-L inhibitory pathway affects both CD4(+) and CD8(+) T cells and is overcome by IL-2. Eur J Immunol 2002;32:634-643.

-26 Freeman GJ, Long AJ, Iwai Y, Bourque K, Chernova T, Nishimura H, Fitz LJ, Malenkovich N, Okazaki T, Byrne MC, Horton HF, Fouser L, Carter L, Ling V, Bowman MR, Carreno BM, Collins M, Wood CR, Honjo T: Engagement of the PD-1 immunoinhibitory receptor by a novel B7 family member leads to negative regulation of lymphocyte activation. J Exp Med 2000;192:1027-1034. Gajewski TF: Failure at the effector phase: immune barriers at the level of the melanoma tumor microenvironment. Clin Cancer Res 2007;13:5256-5261.

-28 Wang C, Thudium KB, Han M, Wang XT, Huang H, Feingersh D, Garcia C, Wu Y, Kuhne M, Srinivasan M, Singh S, Wong S, Garner N, Leblanc H, Bunch RT, Blanset D, Selby MJ, Korman AJ: In vitro characterization of the anti-PD-1 antibody nivolumab, BMS-936558, and in vivo toxicology in nonhuman primates. Cancer Immunol Res 2014;2:846-856. McDermott DF, Sosman JA, Sznol M, Massard C, Gordon MS, Hamid O, Powderly JD, Infante JR, Fasso M Wang YV, Zou W, Hegde PS, Fine GD, Powles T: Atezolizumab, an anti-programmed death-ligand 1 antibody, in metastatic renal cell carcinoma: long-term safety, clinical activity, and immune correlates from a phase Ia study. J Clin Oncol 2016;34:833-842. Caspi RR: Immunotherapy of autoimmunity and cancer: the penalty for success. Nat Rev Immunol 2008;8:970-976.

-31 Atkinson MA, Maclaren NK: The pathogenesis of insulin-dependent diabetes mellitus. N Engl J Med 1994;331:1428-1436.

Steck AK, Rewers MJ: Genetics of type 1 diabetes. Clin Chem 2011;57:176-185

Todd JA: Etiology of type 1 diabetes. Immunity 2010;32:457-467.

Noble JA, Erlich HA: Genetics of type 1 diabetes. Cold Spring Harb Perspect Med 2012;2:a007732. Davies JL, Kawaguchi Y, Bennett ST, Copeman JB, Cordell HJ, Pritchard LE, Reed PW, Gough SC, Jenkins SC, Palmer SM, et al: A genome-wide search for human type 1 diabetes susceptibility genes. Nature 1994:371:130-136. Tisch R, McDevitt H: Insulin-dependent diabetes mellitus. Cell 1996;85:291-297.

-37 Morran MP, Vonberg A, Khadra A, Pietropaolo M: Immunogenetics of type 1 diabetes mellitus. Mol Aspects Med 2015;42:42-60.

38 van Belle TL, Coppieters KT, von Herrath MG: Type 1 diabetes: etiology, immunology, and therapeutic strategies. Physiol Rev 2011;91:79-118.

-39 Conrad B, Trucco M: Superantigens as etiopathogenetic factors in the development of insulindependent diabetes mellitus. Diabetes Metab Rev 1994;10:309-338.

40 Roep B0: The role of T-cells in the pathogenesis of type 1 diabetes: from cause to cure. Diabetologia 2003;46:305-321.

41 Mallone R, Martinuzzi E, Blancou P, Novelli G, Afonso G, Dolz M, Bruno G, Chaillous L, Chatenoud L, Bach JM, van Endert P: CD8+ T-cell responses identify beta-cell autoimmunity in human type 1 diabetes. Diabetes 2007;56:613-621.

42 Bluestone JA, Tang Q: How do CD4+CD25+ regulatory T cells control autoimmunity? Curr Opin Immunol 2005;17:638-642.

43 Martin-Orozco N, Wang YH, Yagita H, Dong C: Cutting edge: programmed death (PD) ligand-1/PD-1 interaction is required for CD8+ T cell tolerance to tissue antigens. J Immunol 2006;177:8291-8295. Okazaki T, Honjo T: The PD-1-PD-L pathway in immunological tolerance. Trends Immunol 2006;27:195-201. 


\section{Case Reports in Oncology}

45 Rajasalu T, Brosi H, Schuster C, Spyrantis A, Boehm BO, Chen L, Reimann J, Schirmbeck R: Deficiency in B7-H1 (PD-L1)/PD-1 coinhibition triggers pancreatic beta-cell destruction by insulin-specific, murine CD8 T-cells. Diabetes 2010;59:1966-1973.

46 Sansom DM: CD28, CTLA-4 and their ligands: who does what and to whom? Immunology 2000;101:169-177.

47 Butte MJ, Keir ME, Phamduy TB, Sharpe AH, Freeman GJ: Programmed death-1 ligand 1 interacts specifically with the B7-1 costimulatory molecule to inhibit T cell responses. Immunity 2007;27:111122.

48 Butte MJ, Pena-Cruz V, Kim MJ, Freeman GJ, Sharpe AH: Interaction of human PD-L1 and B7-1. Mol Immunol 2008;45:3567-3572.

49 Ghiotto M, Gauthier L, Serriari N, Pastor S, Truneh A, Nunes JA, Olive D: PD-L1 and PD-L2 differ in their molecular mechanisms of interaction with PD-1. Int Immunol 2010;22:651-660.

50 Paterson AM, Brown KE, Keir ME, Vanguri VK, Riella LV, Chandraker A, Sayegh MH, Blazar BR, Freeman GJ, Sharpe AH: The programmed death-1 ligand 1:B7-1 pathway restrains diabetogenic effector T cells in vivo. J Immunol 2011;187:1097-1105.

51 McCulloch DK, Palmer JP: The appropriate use of B-cell function testing in the preclinical period of type 1 diabetes. Diabet Med 1991;8:800-804.

52 Klinke DJ 2nd: Extent of beta cell destruction is important but insufficient to predict the onset of type 1 diabetes mellitus. PLoS One 2008;3:e1374.

53 Daaboul J, Schatz D: Overview of prevention and intervention trials for type 1 diabetes. Rev Endocr Metab Disord 2003;4:317-323.

54 Gale EA: Can we change the course of beta-cell destruction in type 1 diabetes? N Engl J Med 2002;346:1740-1742.

-55 Atkinson MA, Eisenbarth GS: Type 1 diabetes: new perspectives on disease pathogenesis and treatment. Lancet 2001;358:221-229.

56 Eisenbarth GS: Type I diabetes mellitus. A chronic autoimmune disease. N Engl J Med 1986;314:13601368 


\section{Case Reports in Oncology}

\begin{tabular}{l|l}
\hline DOI: $10.1159 / 000480634$ & (C) 2017 The Author(s). Published by S. Karger AG, Basel
\end{tabular} www.karger.com/cro

Kapke et al.: Immune Checkpoint Inhibitor-Associated Type 1 Diabetes Mellitus: Case

Series, Review of the Literature, and Optimal Management

Table 1. Patient characteristics

\begin{tabular}{|c|c|c|}
\hline Patient characteristics & Patient 1 & Patient 2 \\
\hline Drug & Nivolumab & Atezolizumab \\
\hline Disease & $\begin{array}{l}\text { Squamous cell carcinoma, } \\
\text { maxillary sinus }\end{array}$ & Urothelial carcinoma \\
\hline Fasting C-peptide (normal range $1.10-4.40 \mathrm{ng} / \mathrm{mL}$ ) & $0.32 \mathrm{ng} / \mathrm{mL}$ & $0.02 \mathrm{ng} / \mathrm{mL}$ \\
\hline Anti-GAD antibody (normal range $0.0-5.0 \mathrm{U} / \mathrm{mL}$ ) & $1,763.6 \mathrm{U} / \mathrm{mL}$ & $>250.0 \mathrm{U} / \mathrm{mL}$ \\
\hline Insulin autoantibody $(<5.0 \mu \mathrm{U} / \mathrm{mL}$ is negative $)$ & $<5.0 \mu \mathrm{U} / \mathrm{mL}$ & $<5.0 \mu \mathrm{U} / \mathrm{mL}$ \\
\hline Islet cell antibody ( $<0.02 \mathrm{nmol} / \mathrm{L}$ is negative) & $0.00 \mathrm{nmol} / \mathrm{L}$ & $0.00 \mathrm{nmol} / \mathrm{L}$ \\
\hline Zinc transporter 8 antibody & $\mathrm{N} / \mathrm{A}$ & $\mathrm{N} / \mathrm{A}$ \\
\hline HLA typing & $\begin{array}{l}\mathrm{DRB} 1 * 08 ; \mathrm{DRB} 1 * 11 \\
\mathrm{DQB} 1 * 03 ; \mathrm{DQB} 1 * 04 \\
\mathrm{DQA} 1 * 04 ; \mathrm{DQA} 1 * 05\end{array}$ & $\begin{array}{l}\mathrm{DRB} 1 * 03 ; \mathrm{DRB} 1 * 04 \\
\mathrm{DQB} 1 * 02 ; \mathrm{DQB} 1 * 03 \\
\mathrm{DQA} 1 * 03 ; \mathrm{DQA} 1 * 05\end{array}$ \\
\hline
\end{tabular}

GAD, glutamic acid decarboxylase; N/A, not applicable. 
Table 2. Review of prior cases with patient characteristics

\begin{tabular}{|c|c|c|c|c|c|c|c|c|c|}
\hline Ref. & $\begin{array}{l}\text { Checkpoint } \\
\text { inhibitor }\end{array}$ & $\begin{array}{l}\text { Date of DM } \\
\text { presentation }\end{array}$ & DKA & HbA1c & $\begin{array}{l}\beta \text {-cell } \\
\text { antibodies }\end{array}$ & High-risk HLA & $\begin{array}{l}\text { Relevant } \\
\text { history }\end{array}$ & $\begin{array}{l}\text { Steroids } \\
\text { used }\end{array}$ & $\begin{array}{l}\text { CPI therapy after } \\
\text { DM diagnosis }\end{array}$ \\
\hline 11 & Nivolumab & 5 months & + & $6.9 \%$ & None & $\begin{array}{l}\mathrm{A} 02: 01 \\
\mathrm{DRB} 1 * 04\end{array}$ & $\begin{array}{l}\text { Autoimmune } \\
\text { thyroiditis }\end{array}$ & NR & NR \\
\hline 11 & Nivolumab & $<1$ month & + & $7.7 \%$ & Anti-GAD & $\begin{array}{l}\mathrm{A} 02: 01 \\
\mathrm{DRB} 1 * 04\end{array}$ & None & NR & NR \\
\hline 11 & Nivolumab & 4 months & - & $8.2 \%$ & $\begin{array}{l}\text { Anti-GAD, } \\
\text { anti-ICA512, } \\
\text { anti-IA2 }\end{array}$ & $\begin{array}{l}\mathrm{A} 02: 01 \\
\mathrm{DRB} 1 * 04\end{array}$ & None & NR & NR \\
\hline 11 & Nivolumab & 1 week & + & $9.7 \%$ & Anti-GAD & A02:01 & Type 2 DM & NR & NR \\
\hline 10 & Nivolumab & $\begin{array}{l}6 \text { weeks } \\
(4 \text { cycles })\end{array}$ & - & NR & None & NR & None & NR & Paused \\
\hline 10 & Nivolumab & 6 weeks & NR & NR & NR & NR & NR & NR & NR \\
\hline 10 & Nivolumab & $\begin{array}{l}3 \text { weeks } \\
\text { ( } 2 \text { cycles) }\end{array}$ & + & NR & Anti-GAD & NR & Type 2 DM & NR & NR \\
\hline 17 & Nivolumab & 30 weeks & + & $8.9 \%$ & None & NR & None & NR & $\begin{array}{l}\text { Discontinued } 6 \\
\text { weeks prior to } \\
\text { DM presentation }\end{array}$ \\
\hline 14 & Nivolumab & $\begin{array}{l}4 \text { months } \\
\text { (6 doses) }\end{array}$ & + & $7.3 \%$ & None & $\begin{array}{l}\text { DRB1 11:01 13:02:01 } \\
\text { DQB1 03:01:01 06:04:01 }\end{array}$ & None & NR & NR \\
\hline 16 & Nivolumab & 12 months & - & $7.0 \%$ & None & $\begin{array}{l}\mathrm{DRB} 1 * 04: 05 \\
\mathrm{DQB} 1 * 04: 01\end{array}$ & None & NR & $\begin{array}{l}\text { Paused for } \\
1 \text { month }\end{array}$ \\
\hline 15 & Nivolumab & $\begin{array}{l}10 \text { weeks } \\
\text { (cycle 6) }\end{array}$ & - & $7.3 \%$ & None & $\begin{array}{l}\text { B*4002 } \\
\text { haplotype }\end{array}$ & None & NR & Paused \\
\hline $\begin{array}{l}\text { This } \\
\text { report }\end{array}$ & Nivolumab & $\begin{array}{l}12 \text { weeks } \\
(6 \text { cycles })\end{array}$ & + & $7.4 \%$ & Anti-GAD & $\begin{array}{l}\text { DRB1*08:11, DQB1*03:04, } \\
\text { DQA1*04,05 }\end{array}$ & None & Prednisone ${ }^{b}$ & Discontinued \\
\hline 11 & Pembrolizumab & $<1$ month & - & $7.4 \%$ & None & DR4 & $\begin{array}{l}\text { Autoimmune } \\
\text { thyroiditis, } \\
\text { psoriasis }\end{array}$ & NR & NR \\
\hline 12 & Pembrolizumab & 3 cycles & + & NR & Anti-GAD & DRB1*04, DQB1*03:02 & None & NR & Continued \\
\hline 8 & Pembrolizumab & $\begin{array}{l}2 \text { weeks after } \\
2 \text { nd injection }\end{array}$ & + & $6.85 \%$ & None & None & $\begin{array}{l}\text { Autoimmune } \\
\text { thyroiditis }\end{array}$ & NR & Continued \\
\hline 10 & Pembrolizumab & $\begin{array}{l}3 \text { weeks } \\
(2 \text { cycles })\end{array}$ & - & & $\begin{array}{l}\text { Anti-GAD, } \\
\text { anti-IA2 }\end{array}$ & NR & None & NR & Continued \\
\hline 9 & Pembrolizumab & $\begin{array}{l}51 \text { weeks } \\
\text { (cycle } 17 \text { ) }\end{array}$ & - & $9.7 \%$ & Anti-GAD & NR & None & NR & Discontinued \\
\hline 7 & Pembrolizumab & $\begin{array}{l}4 \text { weeks } \\
(2 \text { cycles })\end{array}$ & - & $5.8 \%$ & $\begin{array}{l}\text { Anti-GAD, } \\
\text { anti-IA2 }\end{array}$ & NR & None & Prednisone & Continued \\
\hline 13 & PD-1 & $\begin{array}{l}7 \text { weeks } \\
\text { (cycle } 3 \text { ) }\end{array}$ & + & $9.4 \%$ & None & $\begin{array}{l}\text { DR3-DQ2 } \\
\text { DR4-DQ8 }\end{array}$ & None & NR & NR \\
\hline 13 & PD-L1 Abc & $\begin{array}{l}15 \text { weeks } \\
\text { (cycle 5) }\end{array}$ & + & $9.8 \%$ & None $^{a}$ & NR & None & NR & NR \\
\hline 18 & PD-L1 Abc & NR & & & & & & & \\
\hline $\begin{array}{l}\text { This } \\
\text { report }\end{array}$ & Atezolizumab & $\begin{array}{l}24 \text { weeks } \\
(9 \text { cycles })\end{array}$ & - & $7.8 \%$ & Anti-GAD & $\begin{array}{l}\text { DRB } 1 * 03, \text { DRB } 1 * 04 \\
\text { DQB } 1 * 02, \text { DQB } 1 * 03, \\
\text { DQA } 1 * 03, \text { and DQA } 1 * 05\end{array}$ & None & None & Continued \\
\hline
\end{tabular}

CPI, checkpoint inhibitor; DM, diabetes mellitus; DKA, diabetic ketoacidosis; NR, not reported; GAD, glutamic acid decarboxylase. a Only GAD and insulin antibodies were examined. ${ }^{b}$ Steroid administered daily for 2 months due to diffuse colitis that presented simultaneously with DKA. ${ }^{c}$ Specific antibody not listed. 


\section{Case Reports in Oncology}

\begin{tabular}{l|l} 
Case Rep Oncol 2017;10:897-909 \\
\hline DOI: $10.1159 / 000480634$ & $\begin{array}{l}\text { C } 2017 \text { The Author(s). Published by S. Karger AG, Basel } \\
\text { www.karger.com/cro }\end{array}$ \\
\hline
\end{tabular}

Kapke et al.: Immune Checkpoint Inhibitor-Associated Type 1 Diabetes Mellitus: Case Series, Review of the Literature, and Optimal Management

Table 3. Diagnosis and management of immunotherapy-associated T1DM

Diagnostic studies

1 Fasting C-peptide

2 Insulin autoantibody

3 Glutamic acid decarboxylase (GAD) antibody

4 Insulinoma-associated protein 2 (IA2) antibody

5 Zinc transporter (ZnT8) antibody

6 Could consider HLA typing for high risk genotype to develop T1DM

Management

1 Consider admission if patient presents in DKA

2 Insulin therapy using multiple daily injections

3 Avoid all noninsulin therapy for glycemic control

4 There seems to be limited utility for treatment break

5 There seems to be limited utility for immunosuppression with corticosteroids

T1DM, type 1 diabetes mellitus; DKA, diabetic ketoacidosis. 